\title{
Autosomal dominant limb-girdle muscular dystrophy type 1D
}

INSERM

\section{Source}

INSERM. (1999). Orphanet: an online rare disease and orphan drug data base. Autosomal dominant limb-girdle muscular dystrophy type 1D. ORPHA:34516

A subtype of autosomal dominant limb-girdle muscular dystrophy characterized by an adult-onset of slowly progressive, proximal pelvic girdle weakness, with none, or only minimal, shoulder girdle involvement, and absence of cardiac and respiratory symptoms. Mild to moderate elevated creatine kinase serum levels and gait abnormalities are frequently observed. 